\title{
5 \\ Revival of Salmon Resources and Restoration of a Traditional Ritual of the Ainu, the Indigenous People of Japan
}

\author{
Yōsuke Kosaka
}

\section{How Ainu people have traditionally regarded salmon}

Among the Ainu gods' tales compiled and translated into Japanese by the young Ainu woman, Yukie Chiri, two stories out of 13 were on the theme of salmon. Yukie died at the age of 19 in 1922; however, her work has been well-known in Japan through her beautiful poetic translations, such as the following: 'Silver droplets falling, falling all around, golden droplets falling, falling all around' (Chiri 1978: 11). One of the tales about salmon begins with a scene in which, 'A vicious man changed a clear stream into poisonous water by setting up walnut tree trunks in the river' (Chiri 1978: 135). As a result, the salmon could not come back to the headwaters. Having discovered such a malicious act, a son of Okikirmuy, a personal god of the Ainu, fights against the spiteful man and finally defeats him in order to recover the clean water and salmon. This tale, I think, reminds us how important it is to protect the river environment for the salmon. 
The Ainu people regarded famine as being caused by the misconduct of humans. An Ainu oral tradition tells of the God Who Controls Hunting Lands being informed that a human village was suffering from famine. When the god inquired the reason from another god whose spirit possesses the salmon, and from yet another god whose spirit possesses the deer, the God of Salmon answered that humans had forgotten to use a particular wooden stick when killing the salmon, which allows their souls to return to the gods' world. Meanwhile, the God of Deer replied, 'Humans have forgotten to worship the soul of deer, so I stopped supplying them to the human land' (Nabesawa 1998: 83). Following the counsel of the God Who Controls Hunting Lands, humans resumed abiding by their traditional protocols for taking wildlife, and both gods came to forgive humans and supply salmon and deer again. We can conclude that the Ainu people have had their own traditional protocols in making use of natural resources and that these protocols played a role in the Ainu's sustainable maintenance of their surroundings.

In transcribing interviews with Ainu Elders, I often came across the caution, 'Don't collect wild plants exhaustively. You must preserve them for future generations and wild animals' (Kosaka 1994: 190). This way of thinking must come from the Ainu people's concept of not possessing natural resources exclusively. In this context, to catch all salmon for humans to breed artificially would be a perverted deed and one that their gods would not forgive.

\section{The dawn of the modern era and the prohibition against catching salmon in rivers}

Among the four major islands comprising the Japanese Archipelago, Honshū, Kyūshū and Shikoku were territories of Japan during the feudal period. The ethnic Japanese who lived there were mainly engaged in agriculture, especially the cultivation of rice. On the other hand, Hokkaido, together with the southern part of Sakhalin, and the Kuril Islands were the lands of the Ainu people, who supported themselves by hunting, fishing and gathering. Throughout the feudal period, the ethnic Japanese gradually came to exercise control over the Ainu through trade, and by exploiting the Ainu as labourers in fishery camps. Then, Japan's modern era started 150 years ago in 1868, with the Meiji Restoration. 
The Meiji Government annexed Hokkaidō and designated Sapporo as the capital of Hokkaidō prefecture because the presence of a vast alluvial fan there made the site suitable for building a city. The government chose a wide hollow, blessed with a number of springs as the city centre, and placed the Hokkaidō Colonial Commission there. The area designated in this way as the downtown was the very place where the Ainu people had already formed four villages, where they lived subsisting off the salmon coming up the Kotoni River system, a tributary of the Ishikari River, in autumn.

In 1877, in order to make use of such rich fishery resources for industrialisation, the Hokkaidō Colonial Commission established a hatchery at the spring waters beside one of the Ainu villages, and introduced artificial salmon breeding there. Simultaneously, the commission prohibited the Ainu people from catching salmon in all tributaries of the Ishikari River.

In the process of making this decision, the head office of the commission in Sapporo resisted the strict regulation policy that the Tokyo office was willing to carry out. The Sapporo head office insisted, 'The Ainu of Chitose County [along the Chitose River, another tributary of the Ishikari River] live in a mountainous area, so it is difficult for them to subsist other than by fishing salmon' (Yamada 2011: 166). Instead of prohibition, the Sapporo office proposed an alternative plan to introduce a licence system and impose taxes on harvests.

However, the Tokyo office, having the real power, rejected this proposal, stating their position as follows,

We expect artificial breeding will bring about economic benefit in the future. When you take total gains and losses into account, the damage to the minority can be ignored. You should not adhere to residents' welfare. They may be driven to be farmers (Yamada 2011: 168).

The prohibition also targeted Japanese settlers; however, Japanese fishermen usually caught salmon offshore or around the mouth of rivers. So, this policy in actuality affected only the Ainu. 


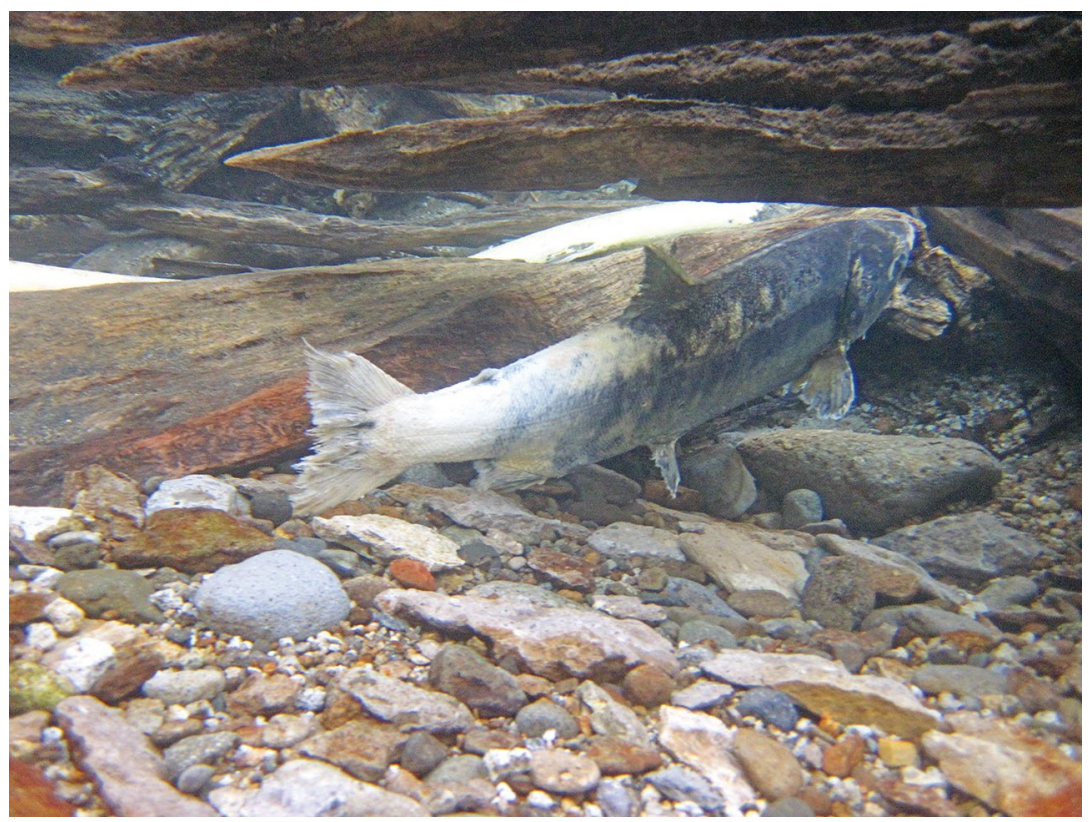

Figure 4. Salmon at the headwaters of the Chitose River.

Source. Photographed by the author, 17 January 2017.

I can point out that this policy, especially the attitude of the Tokyo office, demonstrates the standpoint of colonialism of the Japanese Government, which prioritised industrialisation and the national project in Hokkaidō over the right of an Indigenous people to exist. Moreover, it cannot be overlooked that government officers had an assimilationist view that included converting hunter-gatherers to farmers. Later, the government expanded the prohibition of catching salmon to all rivers in Hokkaidō and this, combined with a sharp decrease in the deer population, caused widespread starvation amongst the Ainu people.

The inhabitants of the four Ainu villages in Sapporo, which had existed at the beginning of the Japanese modern era, dispersed before long and the villages disappeared in the early 1880s (Katō 2017: 56).

To replace the Ainu villages, the official residence of the Hokkaido Governor, the Hokkaidō University campus and the Hokkaidō University Botanical Gardens were constructed on spring-water sites. As the development of the valley of the Kotoni River system as a residential area for homesteaders proceeded, the springs and rivers went dry. 
5. REVIVAL OF SALMON RESOURCES AND RESTORATION OF A TRADITIONAL RITUAL

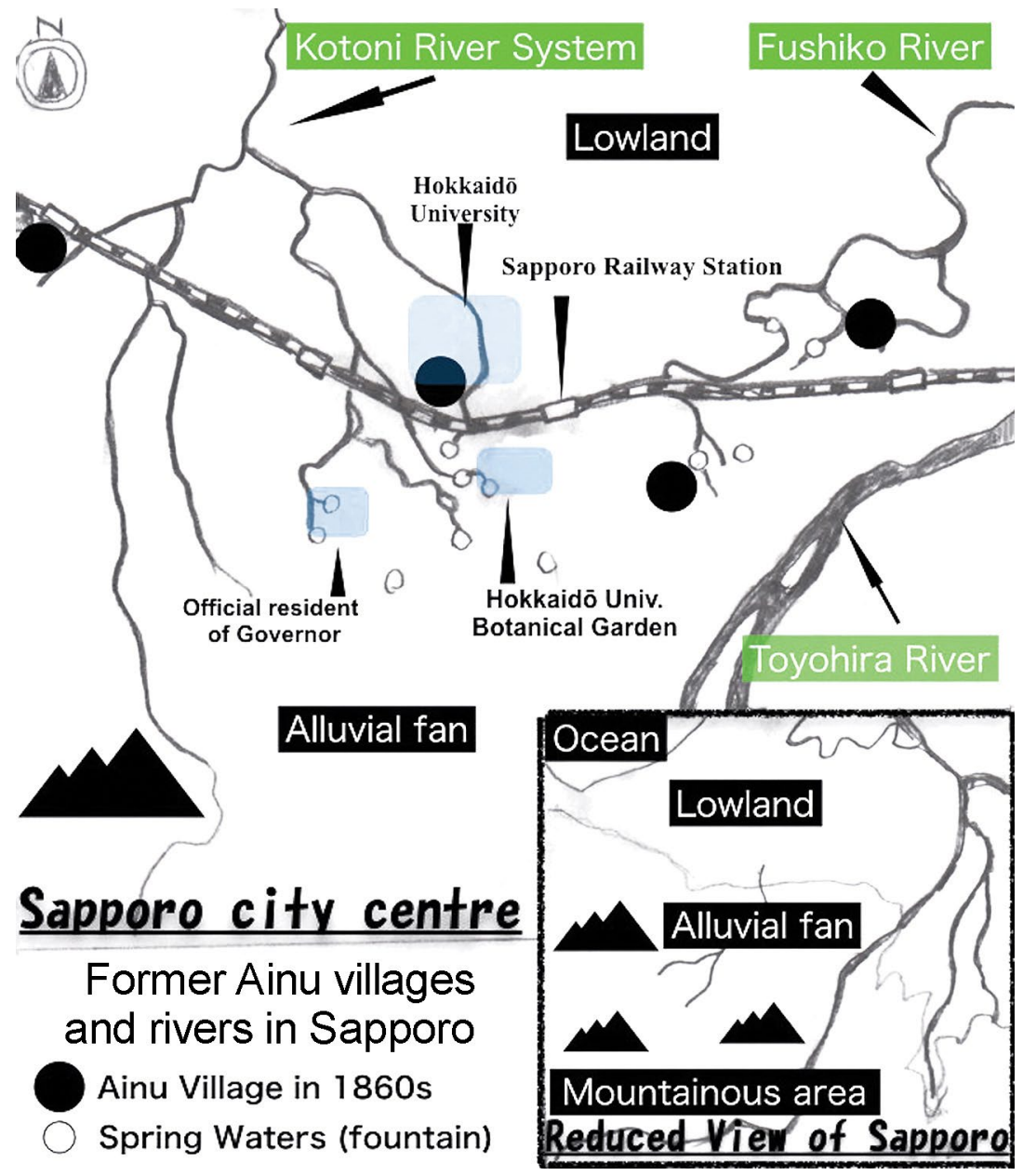

Map 1. Former Ainu villages and rivers in Sapporo.

Source. This map was made by the author based on information provided by Yoshio Katō. 


\section{The period when Ainu 'poachers' were arrested}

Amidst such severe living conditions, a number of Ainu men could not help but poach for salmon in the rivers.

Shigeru Kayano, who became the first member of Ainu origin of the House of Councillors, retraced the day in the 1930s when his father was arrested on a charge of poaching for salmon, in his book Ainu no Ishibumi (Monument of the Ainu) (1990):

Before I enrolled in elementary school, a serious event happened to my family. One day, a policeman entered our house. Just after, the patrol officer asked my father, 'Seitarō, will you go out with me?' My father prostrated himself and replied, 'Yes, I will.' Though my father had lost one eye, I found tears flowing out of both his eyes. I was surprised to see tears pouring from the lost eye. My father was arrested on a charge of salmon theft. He caught salmon every night for my brothers, for old women in the neighbourhood, and for the Gods. However, it was prohibited to catch salmon (Kayano 1990: 74).

Kayano also represented the inner voice of the Ainu people with the following words:

According to a document 120 years ago, the departure of a herd of deer looked as if an enormous brown carpet, covering a slope of a mountain, had moved. A run of salmon looked as if the surface of the river swelled. Wajin [ethnic Japanese], surged into Hokkaidō and pressed 'law' onesidedly on us. Based on such 'law', the Ainu were arrested on charges of theft, when we cut a tree. We have also been arrested, when we catch salmon. My father was one such man (Kayano 1994: 111).

It is our common understanding that we have neither sold nor rented Ainu Mosir [land] to the country of Japan (Kayano 1990: 79).

As the word 'Ainu' has two meanings, one a self-designation and the other, 'humans', 'Ainu Mosir' can be translated in two ways; one is 'the land of the Ainu people', indicating their settled areas in Hokkaidō, Sakhalin and the Kuril Islands. The other translation can be 'the land of Humans', an antonym to 'Kamuy Mosir' (the land of the gods). In Kayano's context, it obviously means 'the land of the Ainu people'. 
Kayano was indignant that the government and ethnic Japanese deprived them of their traditional food resource. And the law prohibiting them from catching salmon was unreasonable.

Even ethnic Japanese Government officials also held antipathy toward government policy. Kanzō Uchimura, an employee of the Hokkaidō Colonial Commission, insisted from a humanitarian perspective that the Ainu people should be treated more generously. He reported in an official document, 'If the government enhanced monitoring for poachers, this policy would cause starvation to death' (cited in Yamada 2011: 178).

His proposal was based on an on-the-spot investigation along the Chitose River in 1882 as an official of Sapporo prefecture, which succeeded the administration of the commission (that is, the Hokkaido Colonial Commission was replaced by Sapporo prefecture). He suggested that what the government should do was first to protect the spawning grounds in the upper reaches of the Chitose River and then allow the Ainu people to catch salmon downstream. However, his superior did not accept his proposal. The government strengthened the monitoring of Ainu poachers and many of them were arrested. The arrest of Shigeru Kayano's father was one 'accomplishment' of such a regulation.

\section{Restoration of a ritual for salmon in 1982}

As time went by, to prevent poaching, the places where salmon are collected for artificial breeding have been relocated from headwater areas to estuaries or streams far downriver. Under this situation, the government could neglect the productivity of the rivers as fisheries and change its rationale for river improvement to the prevention of floods and the supply of irrigation water. Rivers in Hokkaidō were straightened, embanked with concrete and stopped up by erosion-preventing dams. Rivers in urban areas, like the Toyohira River that flows through Sapporo, have become polluted by household drainage containing detergent. Living creatures in Hokkaidō's waterways have disappeared and 'the number of salmon caught in the Toyohira River decreased from 2600 in 1950 to six in 1953' (Yoshizaki 1982: 81-82).

In 1978, the Sapporo citizens' movement 'Come Back Salmon' appeared, combining activities for the improvement of the Toyohira River's environment with the release of salmon fry. They succeeded in finding the first adult salmon returning in 1981 and now the number of salmon coming back has increased to around 2,000 annually. 




Figure 5. Asircepnomi (the ritual to receive the first salmon of the season) on the riverbanks of the Toyohira River, Sapporo. The leader of the prayer is Tatsujirō Kuzuno.

Source. Photographed by the author, 15 September 1993. Used with the permission of Tatsujirō Kuzuno. 
In 1982, after a 100-year interval, the wood carver Shigeo Toyokawa, who was a descendant of one of the Sapporo Ainu villages that had disappeared in the 1880s, in conjunction with Shōji Yūki, an activist for the restitution of Ainu rights, restored the Ainu ritual, Asircepnomi, to receive the first salmon of the season on the riverbanks of the Toyohira River (Figure 5).

Toyokawa negotiated with the Hokkaido prefecture government and succeeded in 1986 in being allowed to catch salmon in the river for this traditional ritual. Following Sapporo, this ritual was restored in Chitose, Asahikawa and Shiraoi, amongst other places, under the name of either Asircepnomi or Kamuycepnomi.

Though the right to catch salmon has been restricted to ritual events, I appreciate that the restoration of ritual is an advancement towards the restitution of the Indigenous people. I think the Ainu people can demand further Indigenous rights to catch salmon to maintain their lifestyle, in other words, demand for the right to exist, because their ancestors depended on salmon for their survival before the Japanese Government annexed Hokkaidō.

The decision delivered by the Sapporo District Court on the Nibutani Dam Case in 1997 gave support to arguments for the Indigenous right to harvest salmon. The verdict by the chief justice, which insisted that the Ainu people's culture must be respected, recognised the Ainu as an Indigenous people. The Law for the Promotion of Ainu Culture was also enacted in 1997; however, the object of the law was confined to only culture and language. In 2008, both Houses of the Diet adopted a resolution to request official recognition of the Ainu people as an Indigenous people. However, at present there is no obvious activity demanding further Ainu rights to catch salmon except for preliminary discussion in Citizens' Alliance for the Examination of Ainu Policy and the Monbetsu Ainu Association led by Satoshi Hatakeyama.

I deeply regret that the citizens' movement 'Come Back Salmon' did not have the vision to connect their activities with the revival of the Ainu culture concerning salmon. It is also regrettable for me that Shōji Yüki, who had been keen on restitution of the Ainu, died in 1983, the year following the first ritual on the Toyohira River. Shigeo Toyokawa died in 2015. 


\section{References}

Katō, Yoshio. 2017. 19 seiki Kōhan no Sapporo, Ishikari no Ainu Minzoku [Ainu People in Sapporo and Ishikari in the Latter Part of the 19th Century]. Sapporo: Sapporodō Shoten.

Kayano, Shigeru. 1990. Ainu no Ishibumi [Monument of the Ainu]. Asahi Bunko, Tokyo: Asahi Shimbun Press.

Kayano, Shigeru. 1994. Tsuma wa Karimono: Ainu Minzoku no Kokoro, Ima [A Wife is a Borrowed Possession: Spirit of the Ainu People Today]. Sapporo: Hokkaidō Shimbun Press.

Kosaka, Yōsuke.1994. Ainu o Ikiru, Bunka o Tsugu: Haha Kina-fuci to Musume Kyōko no Monogatari [I Will Live as an Ainu to Hand Down Culture: The Story of Kina-fuci and her Daughter Kyōko]. Tokyo: Ōmura Shoten.

Nabesawa, Nepki. 1998. 'Kariba o Tsukasadoru Kami to Okikurmi' [The God Who Controls Hunting Lands and Okikurmi]. In Kayano Shigeru no Shinwa Shüsei Vol. 3 [A collection of Ainu myths by Shigeru Kayano], edited by Shigeru Kayano, 74-89: Tokyo: Heibonsha.

Strong, Sarah M. 2011. Ainu Spirits Singing: The Living World of Chiri Yukie's Ainu Shin'yōshū. Honolulu: University of Hawai'i Press.

Yamada, Shin'ichi. 2011. Kindai Hokkaidō to Ainu Minzoku: Shuryō Kisei to Tochi Mondai [Hokkaidō in the Modern Period and the Ainu People: Regulation of Hunting and the Land Problem]. Sapporo: Hokkaidō University Press.

Yoshizaki, Masakazu. 1982. Sakeyo, Toyohiragawa o Nobore [Salmon! Go up the Toyohira River!]. Tokyo: Sōshisha.

Yukie, Chiri. 1978. Ainu Shin'yōshū [Ainu Gods' Tales]. Iwanami Bunko, Tokyo: Iwanami Shoten. 
This text is taken from Indigenous Efflorescence: Beyond Revitalisation in Sapmi and Ainu Mosir, edited by Gerald Roche, Hiroshi Maruyama and Åsa Virdi Kroik, published 2018 by ANU Press, The Australian National University, Canberra, Australia.

doi.org/10.22459/IE.2018.05 